\title{
KERJASAMA BPD DENGAN PEMERINTAH DESA DALAM PEMBANGUNAN DAN PENGELOLAAN DANA DESA
}

\author{
Nurwahidah', Zedi Muttaqin²
}

\author{
${ }^{1}$ Pendidikan Pancasila dan Kewarganegaraan, Universitas Muhammadiyah Mataram, nurwahidah16@gmail.com \\ ${ }^{2}$ Pendidikan Pancasila dan Kewarganegaraan, Universitas Muhammadiyah Mataram, zedi.muttaqin@gmail.com
}

\begin{tabular}{l} 
INFO ARTIKEL \\
\hline Riwayat Artikel: \\
$\begin{array}{l}\text { Diterima: } \quad 20-F e b r u a r i- \\
2018 \\
\text { Disetujui: 25-Maret-2018 }\end{array}$ \\
\hline
\end{tabular}

Kata Kunci:

BPD

Pemerintah Desa

\section{A. LATAR BELAKANG}

Dalam Undang-Undang No. 12 Tahun 2008 tentang perubahan kedua atas Undang-Undang No. 32 Tahun 2004 tentang Pemerintah Daerah mengatakan bahwa "Otonomi daerah adalah hak wewenang dan kewajiban daerah otonom untuk mengatur dan mengurus sendiri urusan pemerintahan dan kepentingan masyarakat setempat sesuai dengan peraturan perundang-undangan (Pasal 1 Angka 5 Undang-UndangNo 32Tahun 2004 tentangPemerintahan Daerah)“ adanya otonomi daerah ini memberikan kesempatan yang lebih besar kepada daerah untuk mengambil keputusan dan memenuhi kebutuhan daerahnya[1]. (H.M Busrizalti, 2013:27)

\section{ABSTRAK}

\begin{abstract}
Abstrak: Kurang efektifnya pelayanan masyarakat dipengaruhi oleh system pemerintahan desa yang kuran maksimal terutama tidak diikutkannya BPD dalam membangun desa. Karena BPD sebagai salah satu unsur dari pemerintah desa ikut andil dalam pembangunan desa, kerena setiap kebijakan, peraturan, ataupun segala program yang dicanangkan oleh pemerintah tidak dapat berjalan tanpa ada persetujuan dari BPD. Tujuan penelitian ini untuk mengetahui kerja sama BPD dengan pemerintah desa dalam pembangunan dan pengelolaan dana desa dan kendala-kendala dalam kerjasama BPD dengan pemerintah desa dalam pembangunan dan pengelolaan dana desa. Metode penelitian yang di gunakan yaitu penelitian kualitatif Dengan pendekatan empiris.Teknik penentuan subjek dalam penelitian ini adalah purposive sampling. Metode pengumpulan data menggunakan metode observasi, wawancara dan dokumentasi, sedangkan Teknik Analisis Data melalui tahapan reduksi data, penyajian data, dan penarikan kesimpulan. Hasil penelitian, bahwa kerjasama BPD dengan kepala desa, Kerjasama Dalam membuat (RKP desa dan APB desa), Kemudian terlihat juga pengelolaan dana desa.
\end{abstract}

Abstract: The lack of effective community service is influenced by the village government system, which has the maximum effect, especially when the BPD is not included in developing villages. Because the BPD as one of the elements of the village government took part in village development, because every policy, regulation, or program launched by the government could not work without the approval of the BPD. The purpose of this study was to determine the cooperation of BPD with village governments in the development and

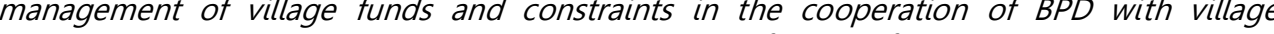
governments in the development and management of village funds. The research method subjects in this study is purposive sampling. Methods of data collection using the method of observation, interviews and documentation, while the Data Analysis Technique through the stages of data reduction, data presentation, and drawing conclusions. The results of the study, that the collaboration of BPD with the village government was optimal, it can be seen from the relationship of BPD cooperation with the village head, Collaboration in making (village RKP and village $A P B$ ). and management of village funds.
Seperti halnya dengan tujuan reformasi dalam sistem pemerintahan daerah di Indonesia salah satunya adalah untuk meningkatkan pelayanan dan kesejahteraan masyarakat. Begitu pula dengan implementasi dari otonomi daerah adalah sebagai upaya untuk mewujudkan kesejahteraan rakyat melalui peningkatan, pelayanan, pemberdayaan, dan peran serta masyarakat, serta peningkatan daya saing daerah .penerapan kebijakan otonomi daerah adalah sebagai upaya untuk memdekatkan pelayanan kepada masyarakat. Pelayanan publik merupakan tugas pokok dari pemerintah guna memenuhi kebutuhan masyarakat agar pelayanan publik tersebut dapat berjalan secara efektif dan efisien, maka peran dari pemerintah desa juga diperlukan. Mengingat pemerintah Desa paling dekat dengan masyarakat dan 
lebih mengetahui apa yang menjadi kebutuhan dari masyarakatnya masing-masing.

Desa yang merupakan lingkup organisasi atau susunan pemerintahan terkecil dan lebih dekat dengan masyarakat, mempunyai peran penting dalam menjalankan otonomi yang di amanatkan oleh konstitusi sebagai jalan menuju rakyat yang sejahtera. Dari sinilah dapat di tentukan keberhasilan pemerintah dalam pembangunan, baik itu dari tingkat daerah maupun pusat melalui tugas pembantuan yang di berikan kepada Pemerintah Desa, kemudian menyalurkan program pembangunan tersebut kepada masyarakat, dalam Undang-Undang No 6 Tahun 2014 tentang Desa telah di sebutkan bahwa Desa merupakan Desa dan Desa adat atau yang disebut dengan nama lain, selanjutnya disebut Desa, adalah kesatuan hukum yang memiliki batas wilayah yang berwenang untuk mengatur dan mengurus urusan pemerintah, kepentingan masyarakat setempat berdasarkan prakarsa masyarakat, hak asal-usul, dan/atau hak tradisional yang di akui dan di hormati dalam sistem Negara Kesatuan Republik Indonesia.

Oleh karena itu, Pemerintah Desa di bentuk guna menyelenggarakan urusan pemerintahan dan kepentingan masyarakat Desa setempat, sedangkan untuk kewenangan dari Desa (Pasal 19 Undang-Undang No. 6 Tahun 2014 tentang Desa) meliputi kewenangan berdasarkan hak asal-usul, kewenangan lokal berskala Desa dan kewenangan yang di tugaskan oleh pemerintah, pemerintah daerah Provinsi, atau pemerintah daerah Kabupaten/Kota.

Penyelenggaraan pemerintahan Desa merupakan subsistem dari sistem penyelenggaraan pemerintahan, sehingga Desa mempunyai kewenangan untuk mengatur dan mengurus kepentingan masyarakat.Sama halnya dengan tinggkat daerah maupun pusat di dalam menjalankan pemerintahan dibantu dan bekerjasama dengan badan Eksekutif maupun Legislatif dengan adanya pembagian kekuasaan. Begitu pula di tingkat Desa, dalam menjalankan roda pemerintahannya, Kepala Desa tidaklah bekerja sendiri, namun di bantu juga oleh perangkat Desa yang lain seperti Sekertaris Desa dan yang lainnya. Badan Permusawaratan Desa (BPD) yang merupakan perwujudan dari sistem demokrasi, di dalam Undang-UndangNomor 6 Tahun 2014 tentang Desa mengatakan bahwa BPD merupakan lembaga yang melaksanakan fungsi pemerintahan yang anggotanya merupakan wakil penduduk Desa berdasarkan keterwakilan wilayah dan ditetapkan secara demokrasi.BPD dilihat dari kewenangannya dapat dikatakan sebagai lembaga Legislatif di tingkat Desa, sedangkan pemerintah Desa dan perangkat desa yang lainya adalah lembaga Eksekutif.

Dibentuknya BPD merupakan hasil dari reformasi sebagai upaya dari perwujudan demokrasi di tinggkat Desa.BPD mempunyai pengaruh yang sangat penting dalam pemerintahan Desa, yaitu untuk menggali, menampung, menghimpun, dan menyalurkan aspirasi masyarakat. Sehingga BPD di tingkat Desa menjadi tumpuan harapan masyarakat terhadap programprogram yang akan dilaksanakan oleh pemerintah, khususnya bagi kesejahteraan masyarakat dan pembangunan Desa itu sendiri. (HAW. Wdjaja, 2004:3).

Namun aspirasi dan kebutuhan masyarakat yang telah mampu digali dan tampung oleh BPD tidak akan mampu disalurkan jika tidak terdapat kerja sama anrata BPD dan pemerintahan Desa yang harmonis, dalam memenuhi kebutuhan masyarakat yang kemudian akan berimbas kepada pembangunan itu sendiri. Berdasarkan observasi awal yang dilakukan oleh peneliti Seperti yang di jelaskan di atas bahwa di Desa Ncandi,Kecamatan Madapangga,Kabupaten Bima, Provinsi Nusa Tenggara Barat dengan wilayah dataran rendah, mata pencaharian masyarakatnya mayoritas adalah petani, belum ada kebijakan pemeritah yang berkaitan dengan pembangunan Desa, selain dari bidang infrastruktur dan melaksanakan program dari Pemerintah, Pemerintah Daerah Provinsi, dan Pemerintah Daerah Kabupaten.

Untuk pembangunan infrastruktur masih terfokus kepada perbaikan jalan yang hanya berpusat di beberapa tempat tanpa menghiraukan tempat yang lain, oleh karena itu, BPD sebagai salah satu unsur dari pemerintah Desa ikut andil dalam pembangunan Desa, kerena setiap kebijakan, peraturan, ataupun segala program yang dicanangkan oleh pemerintah tidak dapat berjalan tanpa ada persetujuan dari BPD.Adapun Desa tempat peneliti melakukan penelitian adalah di Desa Ncandi, Kecamatan Madapangga, Kabupaten Bima, Provinsi NTB.

Desa Ncandi merupakan Desa kecil yang penduduknya kurang dari 200oorang dan pembangunan infrastruktur di desa ini jika dilihat dari luar terbilang bagus akan tetapi ketika kita memasuki Desa masih terdapat pembangunan infrastruktur yang kurang memadai. Salah satu contohnya adalah polindes, perbaikan jalan menuju ruhu atau di dekat jalan lintas sumbawa, lapangan olahraga seperti (lapangan sepek bola, voli, bulu tangkis). Kondisi ini juga sedikit menghambat perkembangan Desa, oleh sebab itu, penting kiranya untuk mengetahui bagaimana kerja sama BPD dengan pemerintah Desa di Desa ini berkaitan dengan pembangunan dan pengelolaan dana Desa, kenapa pembangunan di Desa ini tidak merata.

BPD dengan wewenangan untuk menyalurkan segala aspirasi masyarakat dapat mempertimbangkan apakah segala ketentuan yang ingin dilaksanakan oleh pemerintah Desa maupun memenuhi kebutuhan masyarakat atau bahkan sebaliknya, serta memberikan masukan kepada pemerintah Desa berkaitan dengan aspirasi masyarakat.

\section{B. METODE PENELITIAN}

\section{Metode Yang Digunakan}

Penelitian ini mengunakan metode penelitian kualitatif dengan mengunakan pendekatan empiris, 
penelitian kualitatif dalam pelaksanaan penelitiannya menekankan pada proses dan tidak menekankan hasil seperti penelitian kuantitatif. Sedangkan penelitian empiris yaitu penelitian yang menghasilkan sesuatu yang dapat dilihat dan dapat dirasakan oleh peneliti sendiri dan orang lain dan dapat digunakan atau diberlakukan di tempat lain dalam waktu yang berbeda. Lokasi penelitian yang akan digunakan dalam penelitia ini adalah Desa Ncandi, Kecamatan Madapangga Kabupaten Bima.

\section{Subyek Penelitian}

Subjek penelitian atau responden adalah orang yang di minta untuk memberikan keterangan tentang suatu fakta atau pendapat. Subjek penelitian[2] adalah subjek yang dituju untuk di teliti oleh peneliti. Jadi, subjek penelitian merupakan sumber informasi yang digali untuk mengungkapkan fakta-fakta di lapangan. Penentu subjek peniliti atau sampel dalam peneliti kualitatif.

Subjek penelitian atau responden dalam penelitian ini mengambil purposive sampling. Purposive sampling[3] merupakan teknik pengembilan sampel yang di tentukan dengan menyesuaikan pada tujuan penelitian atau pertimbangan tertentu. Adapun yang menjadi subyek dalam penelitian ini antara lain: Badan Permusyawaratan Desa (BPD), pemerintah Desa, Kepala Dusun, Tokoh Masyarakat.

\section{Teknik Pengumpulan Data}

a. Observasi

Observasi merupakan pengumpulan data yang menggunakan pengamatan terhadap objek penelitian. Metode observasi dalam penelitian ini digunakan untuk mengamati Kerja Sama BPD Dengan Pemerintah Desa Dalam Pembangunan dan Pengelolaan Dana Desa (Studi Kasus di Desa Ncandi Kecamatan Madapangga Kabupaten Bima)[4].

Observasi dalam penelitian ini dimulai dengan mengamati keadaan topografi Desa Ncandi, jumlah penduduk, kemudian observasi dilanjutkan dengan mengamati keadaan di dalam Balai Desa,dan langkah selanjutnya dengan mengamati kerja sama BPD dengan Pemerintah desa dalam pembangunan dan pengelolaan dana Desa.

Dari hasil observasi kemudian dapat diambil kesimpulan atas apa yang telah diamati dan dapat digunakan sebagai pembandingan antara hasil wawancara yang dilakukan dengan hasil pengamatan apakah ada kesusaian atau tidak.

b. Wawancara

Wawancara adalah percakapan dengan maksud tertentu,percakapan itu dilakukan oleh dua pihak,yaitu pewawancara (interviewer) yang mengajukan pertanyaan,dan terwawancara (interviewee) yang memberikan jawaban atau pertanyaan itu[4].

Wawancara tidak tersruktur merupakan wawancara yang berbedadengan yang terstruktur. Wawancara semacam ini digunakan untuk menemukan informasi yang bukan baku atau informasi tunggal,wawancara ini sangat berbeda dari wawancara terstruktur,pertanyaan biasanya tidak disusun terlebih dahulu,malah disesuaikan dengan keadaan dan ciri yang unik dari responden.

Apabila dilihat dari pengertian wawancara terstruktur dan tidak terstruktur, maka jenis wawancara yang digunakan dalam penelitian ini adalah wawancara terstruktur dan tidak terstruktur karena disini pewawancara disamping menetapkan sendiri masalah dan pertanyaan-pertanyaan disusun terlebih dahulu sebelum diajukan dan juga menggali pertanyaan yang sudah ditanyakan secara mendalam dan langsung.

\section{c. Dokumentasi}

Metode dokumentasi adalah metode yang digunakan mencari data mengenai hal-hal atau variabel yang berupa catatan, transkip, buku, surat kabar, majalah, prasasti, notulen rapat, lengger, agenda, dan sebagainya[5]. Dokumentasi digunakan untuk menunjang data-data hasil wawancara maupun observasi, alasan pengunaan dokumentasikarena kerja sama BPD dengan Pemerintah Desa dalam pembangunan dan pengelolaan dana Desatidak lepas dari adanya dokumen sehingga dalam hal ini dapat melengkapi data yang diperlukan dalam penelitian ini.

Dokumentasi yang digunakan dalam penelitian ini yang berhubungan dengan kerja sama BPD dengan Pemerintah Desa dalam pembangunan dan pengelolaan dana Desa yaitu data-data mengenai peraturanperaturan desa, data anggota BPD, data-data tentang pembangunan dan pengelolaan dana desa, keadaan umum daerah penelitian seperti:keadaan geografisnya, batas-batas wilayah, jumlah penduduk, dan dtruktur organisasi pemerintahan desa dan daftar nama anggota.

4. Teknik Analisis Data

Aktivitas dalam analisis data kualitatif dilakukan secara interaktif dan berlangsung secara terus-menerus sampai tuntas, sehingga datanya lebih menekankan pada aspek pemahaman secara mendalam terhadap suatu masalah dari pada melihat permasalahan itu untuk penelitian[6].

Metode analisis data yang digunakan dengan tahapan sebagai berikut[7]:

a. Reduksi data

Reduksi data adalah proses pemilihan, pemusatan perhatian pada penyederhanaan, pengabstrasiksian dan transpormasi data kasar dari catatan tulisan selama di lapangan. Untuk mereduksi data peneliti membuat ringkasan kontak, mengembangkan kategori, pengkodean dan membuat catatan refleks yang bermaksud menajamkan, penggolongan, mengarahkan yang tidak berlaku. Kemudian mengorganisasikan sedemikian rupa sehingga kesimpula yang tepat, ini dilakukan secara terus-menerus selama penelitian berlangsung.

b. Penyajian data

Penyajian data adalah merupakan sekumpulan informasi tersusun yang memberikan kemungkinan 
adanya penarikan kesimpulan dan penarikan tindakan. Data teks naratif penelitian dijadikan dalam bentuk metrik, diagram, jaringan, dan tabel yang dirancang peneliti untuk menggabungkan informasi dan diinformasikan dalam bentuk sederhana dan bentuk terpadu, sehingga dapat melihat apa yang sedang terjadi. c. Kesimpulan dan verifikasi

Kesimpulan verivikasi adalah upaya yang diperoleh selama penggumpulan data berlangsung. Penulis melakukan kesimpulan sejak awal pengumpulan data. Kesimpulan yang kurang jelas meningkatkan semakin rinci dan menyusun laporan final selesai. Untuk kesimpulan final peneliti terus mengadakan pengujian (verivikasi) selama peneliti berlangsung dengan berbagai cara antara lain meninjau catatan di lapangan.

\section{HASIL DAN PEMBAHASAN}

\section{Hubungan kerjasama BPD dengan kepala Desa}

Manusia merupakan unsur terpenting dalam suatu organisasi karena unsur-unsur lain yang dimiliki organisasi seperti uang, material, mesin dan metode kerja dapat memberikan manfaat bagi organisasi jika manusia yang ada dalam organisasi itu mempunyai sumber daya yang baik bukan sebaliknya. dalam kehidupannya manusia membutuhkan manusia lainnya untuk mencukupi kebutuhan hidupnya, termasuk dalam sebuah kelompok/lembaga saling mempunyai relasi namun ada hal yang paling penting yaitu sumber daya manusia yang akan berbicara disitu. Kerjasama antara organisasi akan terealisasi dengan baik manakala di dalam organisasi itu mempunyai sumber daya yang mempuni karna dengan begitu sumber daya yang dimiliki oleh setiap lembaga menentukan tercapainya tujuan bersama. kerjasama antara lembaga BPD dan Pemerintah Desa membutuhkan hal yang demikian.

Berkaitan dengan penelitian ini yang memfokuskan pada kerjasama BPD dengan Pemerintah Desa dalam pembangunan dan pengelolaan dana Desa (Studi kasus Ncandi Kecamatan Madapangga Kabupaten Bima). Peneliti menemukan bahwa anggota lembaga BPD memiliki tingkat kemampuan yang kurang mempuni dalam menjalankan tugas dan fungsinya sebagai BPD. Hal ini di benarkan oleh salah satu responden yang menyatakan bahwa salah satu kendala yang di hadapi BPD dengan pemerintah Desa dalam kerjasama adalah masalah dari BPD itu sendiri. Pada saat peneliti menanyakan apa saja kendala yang dihadapi oleh BPD dengan pemerintah Desa dalam kerjasamanya sebagai lembaga legislative dan eksekutif ditingkat Desa. Seperti terlihat dalam hasil wawancara dengan Bapak M. Said H. Mansur selaku Kepala Desa Ncandi Berikut ini:

"Allhamdulillah selama ini kami dengan BPD telah banyak menjalin kerjasama dalam pembangunan Desa Ncandi melalui programprogram yang di butuhkan oleh masyarakat misalnya pembukaan jalan baru, drainase dan masih banyak lagi, ya... walaupun masih ada kendala-kendala yang terletak dari anggota BPD itu sendiri yang kurang memahami tugasnya sebagai BPD misalnya terlihat ketika akan di adakannya Musrebang Desa, BPD tidak mampu menginformasikan kepada masyarakat bahwa akan di adakan Musrembang Desa di kantor Desa, dan pada akhirnya kami sendiri yang turun tangan untuk memberikan informasi itu kepada masyarakat, hal itu sering terjadi ketika mendekati Musrembang Desa dan yang saya ketahui juga mereka memiliki profesi lain selain BPD misalnya ada yang sebagai petani, ada yang pedagang, ada yang peternak, dan ada pula yang pedagan sapi, bahkan ada juga anggota BPD memiliki profesi lebih dari 2 profesi." (wawancara tanggal 15 Januari 2018).

Dari hasil wawancara di atas dapat di lihat bahwa dalam kerjasama BPD dengan Pemerintah Desa sudah optimal dengan melakukan sosialisasi musrembang Desa meskipun masih ada kendala-kendala yang di hadapi oleh BPD seperti memiliki kesibukan lain menjadi petani, pedagang dan bahkan lebih dari 2 profesi.

Kemudian menurut Bapak Suaeb (ketua BPD) dalam wawancara dengannya menyatakan bahwa:

"Kerjasama kami selama ini sih berjalan dengan baik misalnya dalam melakukan Musrembang Desa sampai pengawasan dalam pelaksanaan pemerintahan. Lihat saja pembangunan Desa Ncandi sekarang yang lumayan bagus ketimbang Desa-Desa tetangga bahkan tahun kemarin Desa Ncandi menjadi Desa nomor 3 dalam lomba keindahan Desa seKabupaten Bima, sewalaupun masih ada pembangunan yang sedang berjalan misalnya pembukaan jalan baru untuk mempermudah masarakat dalam perjalanan kesawahnya masing-masing dan ini pun adalah hasil dari permintaan masarakat Ncandi untuk membuka jalan baru dalam Musrembang Desa. Namun ada beberapa kendala yang kami hadapi dari anggota BPD sendiri, anggota kami kan memiliki profesi lain selain BPD. ya adek tau sendiri lah kesibukannya, apalagi gaji yang kami dapat sebulan itu untuk anggota $R p 500$ ribu, sekertaris $R p 750$ ribu dan untuk ketua 900 ribu perbulan inikan gak cukup buat keperluan anak, istri sehari-hari di rumah, dan kami juga belum mempunyai kantor sendiri sedangkan di kantor Desa ruangannya sudah kepake oleh Bidan Desa maka kami otomatis hanya menjalankan tugas-tugas kami dari rumah ke rumah anggota BPD, kemarin memang masyarakat mengusulkan untuk membuat kantor BPD agar kerja kami 
maksimal dan alhamdulilah sedang di bangun"

(wawancara tanggal 17 Januari 2018)

Dari hasil wawancara di atas dapat di simpulkan bahwa kerjasama BPD dengan Pemerintah Desa dalam pembangunan dan pengelolaan dana Desa sudah berjalaan sesuai dengan Undang-Undang Nomor 6 Tahun 2014 tentang Desa[8], walaupun masih terdapat kelemahan-kelemahan dalam pelaksanaan kerjasama tersebut misalnya dari dalam internal BPD yang memiliki profesi lain lantaran gaji yang di dapatkan jauh dari kebutuhan sehari-hari, ini menjadi pemicu dalam pelaksanaan kerjasama tersebut dan beberapa faktor lainnya misalnya tidak memiliki ruangan kerja, sewalaupun dalam banyak hal kerjasama BPD dengan Pemerintah Desa selama ini cukup mentereng dengan menyandang desa nomor 3 dalam lomba keindahan Desa se-Kabupaten Bima. tanpa pembanguna yang strategis maka peringakat 3 se-kabupaten bima tidak akam mungkin di sandang oleh Desa Ncandi.

Masih banyak lagi mengenai keberhasilan kinerja BPD dengan Pemerintah Desa dalam pembangunan dan pengelolaan danaDesa seperti hasil wawancara dengan Bapak M. Umar selaku Kepala Dusun sambi pajo menyatakan bahwa:

"kalo menurut saya sih pembangunan diDesa Ncandi sudah bagus dengan contoh pembuatan wc umum, dan sebentar lagi saya dengar kabar akan di buat lapangan futsal, pagarnisasi sepanjang jalan di Desa Ncandi, Dan yang paling kami butuhkan adalah pembuatan drain ac yang sebelumnya kalo musim hujan biasanya banjir sering masuk di rumah warga. Kalo masalah musrembang desa Memang biasanya selama ini yang menginformasikan akan di adakan Musrembang desa itu adalah pihak staf Desa" (wawancara tanggal 18 januari 2018)

Dari hasil wawancara di atas dapat di simpulkan bahwa pelaksanaan kerja sama BPD dengan pemerintah Desa memiliki hasil nyata dalam pembangunan dan perencanaan anggaran yang di masukan di RKPdes sebagai tahap awal dalam pengelolaan atau pengalokasian dana Desa Ncandi, jadi kerjasma antara BPD dengan Pemerintah Desa dalam pembangunan dan pengelolaan dana Desa sudah optimal, terlepas dari anggota BPD yang memiliki kemampuan yang kurang dalam mensosialisasikan akan di adakan Musrembang Desa adalah manusiawi apalagi mereka memiliki tingkat pendidikan sanpai SMA.

\section{Tahapan-tahapan kerjasama BPD dengan Pemerintah Desa dalam pembangunan dan pengelolaan dana Desa.}

Setiap kerja sama pasti memiliki tahap susunan kerja yang harus di lewati agar tujuan dari kedua belah pihak mencapai tujuan yang di inginkan secara bersama termasuk juga Kerjasama BPD dengan pemerintah Desa dalam proses perencanaan sampai proses pelaksanaan misalnya mulai dari Musrembang Desa sampai ke tahap selanjutnya. Seperti terlihat dalam hasil wawancara dengan pak M. Said H. Mansur selaku Kepala Desa Ncandi Berikut ini:

1) Pemerintah Desa, BPD, dan masyarakat melakukan Musrembang Desa.

2) Menyusun RKPDesa sesuai hasil Musawarah Desa

3) Menyusun APBDesa sesuai RKPdesa dan Perbub.

4) Soasialisasi ke masyarakat/papan informasi

5) Pelaksanaan. (Wawancara tanggal 15 Januari 2018)

Dari hasil wawancara di atas dapat di simpulkan bahwa tahap kerjasama antara BPD dengan Pemerintah Desa sudah sesuai dengan aturan main mulai dari Musrembang Desa sampai tahap pelaksanaan kegiatan.Kemudia menurut anggota BPD Bapak Samsir dalam wawancara dengannya menyatakan bahwa:

"BPD melakukan Musremabang Dusun di tingkat dusun untuk membicarakan kebutuhan masyarakat di tiap-tiap Dusun, hasil itu akan di bawah ke Musrembang Desa, kemudian RKPDesa, selanjutnya menyusun APBDesa, kemudian pemerintah Desa mensosialisasikan program kegiatan Desa." (Wawancara tanggal 17 Januari 2018)

Dari hasil wawancara di atas dapat di simpulkan bahwa kerja sama BPD dengan Pemerintah Desa sudah optimal dengan susunan kegiatan yang sistematis sehingga program-program yang di inginkan oleh masyarakat dapat teralisasi dengan baik dan pada tahap awal Pemerintah Desa, BPD dan masyarakat melakukan Musrembang Desa kemudian dari keputusan itu akan dirancang RKPDesa, kemudian tahap selanjutnya menyusun APBDesa sesuai dengan RKPDesa dari hasil aspirasi masyarakat setelah itu Pemerintah Desa melakukan sosialisasi kegiatan dan pemasangan papan informasi.

\section{Kerjasama Dalam membuat Rencana Kerja Pemerintah Desa (RKP desa) dan APBdesa.}

Musyawarah perencanaan pembangunan Desa (Musrenbang Desa) adalah sebuah forum musyawarah tahunan para pemangku kepentingan (stakeholders) Desa untuk menyepakati Rencana Kerja Pemerintah Desa (RKP Desa) pada tahun anggaran yang direncanakan.Penyusunan RKP Desa harus didasarkan dan mengacu pada RPJM Desa. Dalam penyusunannya setiap elemen Desa baik Pemerintah Desa maupun seluruh lapisan masyarakat harus terlibat agarperencanaan pembangunan yang dihasilkan akan sesuai dengan kebutuhan masyarakat dan bukan daftar keinginan elit Desa belaka. Maka sesuai dengan kebutuhan masarakat Desa pada penelitian ini Desa Ncandi Kecamatan Madapangga Kabupaten Bima perencanaan pembangunan di tahun 2018 ini yaitu seperti PembangunanJalan menuju Puncak Doro Ncandi sekaligus Penataan Tempat (Pariwisata) yang menargetkan Rp.90.000.00o, belum teralisasi sepenuhnya, kemudian Pembangunan Lapangan Futsal 
di targetkan sekitar Rp. 45.00o.ooo belum terealisasi, selanjutnya Pembangunan Polindes yang membutuhkan dana sekitar Rp. 158.001.838.68 belum teralisasi selanjutnya Pembangunan Mushollah yang menelan biaya sekitar Rp. 83.300.000.01 belum terealisasi sesuai dengan rencana.

Seperti terlihat dalam hasil wawancara dengan Bapak Kepala Desa Ncandi Bapak M. Said H.Mansur

"Pada saat melakukan Musrembang Desa biasanya saya memberikan kata sambutan sekaligus menjelaskan kepada masarakat mengenai tujuan pelaksanaan pembangunan tersebut, kemudian saya melibatkan kelompokkelompok masyarakat yang menghadiri acara Musrembang Desa dalam menyusun perencanaan tersebut dengan tujuan memperoleh ide-ide, ataupun saran agar pelaksanaan pemabungunan sesuai dengan kebutuhan masyarakat" (wawancara tanggal 15 Januari 2018)

Kemampuan dalam merencanakan pembanguna Desa sangat menentukan harapan masyarakat Desa maka dengan demikian sebaiknya Kepala Desa terlebih dahulu mengadakan Musawarah kemudian dalam Musyawarah itu di jelaskan tujuan dari pembangunan yang di inginkan setelah itu barulah menentukan langakah selanjutnya dalam pelaksanaan pembangunan, ide dan saran-saran atau tanggapan masyarakat kemudian di rumuskan dalam perencanaan pembangunan Desa.

Dalam hasil wawancara dengan salah satu responden Bapak Abdul Kadir yaitu:

"Kepala Desa biasanya menjelaskan tujuan dari pelaksanaan pembanguna kepada masarakat melalui Musyawarah Desa tetapi Kepala Desa tidak membuat langkah-langkah yang perlu dilakukan dalam pelaksanaan pembangunan. Seharusnya Kepala Desa itu membuat langkah-langkah misalnya: dalam hal pengerjaan apa saja yang sepetinya di dahulukan, dalam pengadaan bahan, kapan bahan tersebut harus sampai di lokasi pembangunan, kemudian peralatan apa saja yang di perlukan atau di sediakan" (Bapak Abdul Kadir Wawancara tanggal 21 Januari 2018)

Bahwa Kepala Desa hanya mampu melaksanakan Musyawarah dan menjelaskan tujuan dari pelaksanaan pembangunan, akan tetapi Kepala Desa tidak menentukan langkah-langkah apa yang di kerjakan oleh masyarakat dan aparat Desa. Kemudian setelah penyusunan RKP pihak BPD dengan Pemerintah Desa barulah melakukan penyusunan APBDesa yang akan menjadi pedoman/dasar dalam pelaksanaan kegiatan Pemerintah Desa selama 1 tahun ke depan dan APBDesa juga akan menjadi acuan BPD dalam melakukan pengawasan kinerja Pemerintah Desa selama 1 tahun. Disinilah peran BPD yang akan menentukan sehat atau tidaknya pelaksanaan Pemerintahan Desa kaitannnya dengan pengelolaan dan pembangunan Desa seperti dalam hasil wawancara di bawah ini:

"kami dengan BPD selalu menyusun APBDesa secara bersama" (M.Said H.Mansur, wawancara tanggal 23 Januari 2018)

Kemudian menurut Bapak Suaeb (ketua BPD) dalam wawancara dengannya menyatakan bahwa:

"kami biasanya selalu terlibat dalam pembuatan APBDesa" (wawancara tanggal 24 Januari 2018)

Bahwa kerjasama BPD dengan Pemerintah Desa sudah optimal di lihat dari keterlibatan BPD dalam penyusunan APBDes.

Kemudian menurut salah satu responden yang langsung mengedit penyususnan APBDesa Bapak Syarifudin selaku staf Desa di Bidang Perencanaan menyatakan bahwa:

"Biasanya saya di bidang perencanaan disuruholeh pak Kepala desa untuk mengedit langsung APBDesa" (wawancara tanggal 24 januari 2018)

Kerjasama BPD dengan Pemerintah Desa dalam menyusun APBDesa sudah optimal.Pemerintah Desa membutuhkan persetujuan BPD dalam segala kegiatan termasuk APBDesa. APBDesa ini akan di bawah ke pihak Camat Madapangga setelah di setujui di Camat Madapangga baru APBDesa di bawakan lagi ke pihak Pemda (BPMDes) setelah di setujui lagi oleh pihak tersebut barulah anggaran akan segera di cairkan, dalam kontemporer itu pihak Pemerintah Desa melakukan sosialisasi kepada masyarakat dan pembuatan papan informasi terkain kegiatan dan anggaran yang di setujui oleh pihak Pemerintah Daerah dengan kata lain hal ini adalah keterbukaan informasi kepada masyarakat Desa Ncandi, sesuai dengan hasil wawancara dengan beberapa responden salah satunya Bapak M. Saleh selaku Sekretaris Desa Ncandi di bawah ini:

"kami selalu mensosialisasikan bahkan kami mengumumkannya secara langsung di Mesjid Bayitu Rahman Ncandi dan kami juga memasang papan informasi di sejumlah tempat setelah BPMDes menyetujui APBDesa yang kami ajukan" (wawancara tanggal 25 Januari 2018)

\section{Kendala-Kendala Dalam Kerjasama BPD Dengan Pemerintah Desa Dalam Pembangunan Dan Pengelolaan Dana Desa.}

Dari hasil penelitian terhadap responden terdapat hambatan yang di alami oleh kerja samaBPD dengan Pemerintah Desa dalam pembangunan dan pengelolaan dana Desa. Dalam hal ini untuk mencapai tujuan pembangunan harus adanya kerja sama antara BPD, Pemerintah Desa, maupun masyarakat setempat agar semua yang di rencanakan bersama dapat tercapai sesuai dengan ke butuhan masyarakat, akan tetapi di Desa Ncandi belum tercapai sepenuhnya pembangunan 
di karenakan kurangnya partisipasi masyarakat. Adapun hambatan-hambatan BPD dengan Pemerintah Desa dalam pembangunan dan pengelolaan danaDesa yaitu sebagai berikut:

a. Kendala Dalam membuat perencanaan pembangunan Desa melalui Musremabang Desa sebagai berikut:

1. Kurang optimalnya peran BPD dalam mensosialisasikan akan di adakannya Musrembang Desa.

2. Sulitnya mengumpulkan masyarakat Desa ketika kegiatan Musrembang Desa.

3. Masyarakat sebagian kecil kurang aktif ketika Musrembang Desa dalam perencanaan pembangunan. (Bapak M.Said H.Mansur wawancara tanggal 29 Januari 2018)

b. Masalah sulitnya mengambil keputusan karena banyaknya kebutuhan masyarakat dan kelompokkelompok masyarakat.

1. Dalam mengambil keputusan Pemerintah Desa sering di hadapkan pada perbedaan pendapat antara kelompok masyarakat.

2. Sulitnya menentukan prioritas dalam pelaksanaan pembangunan.

3. Rendahnya pemahaman masyarakat dalam menyerap pengarahan yang di sampaikan Pemerintah Desa.

4. Masyarakat yang mengahdiri musrembang desa hanya sedikit. (Bapak Suaeb wawancara 30 januari 2018)

c. Kendala Dalam penyelenggaraan kegiatan pembangunan desa.

1. Masyarakat yang di ajak dalam kegiatan pembangunan tidak bisa di ajak secara sukarela.

2. Kurangnya jelasnya pembagian tugas antara aparat desa dengan masyarakat.

3. Kurangnya pengawasan oleh Kepala Desa dan BPD dalam kegiatan pembangunan lantaran jarang hadir di lokasi.

4. Kurangnya partisipasi masyarakat dalam kegiatan pembangunan.

5. Pelaksanaan Pembangunan kurang tepat waktu karena kendala cuaca. (Bapak H.M.Saleh wawancara tanggal februari 2018). 6.Kendala dari persetujuan pemerintah daerah 7. Pihak Camat dan Pemda sering merefisi program kegiatan yang di ajukan oleh pihak Desa melalui APBDesa.

8. Pemerintah Desa sering kewalahan dengan merombak APBDesa. (Bapak Syarifudin wawancara tanggal 1 Februari 2018)

\section{SIMPULAN DAN SARAN}

Hasil penelitian ini menunjukkan bahwa Pertama, Kerjasama BPD dengan Pemerintah Desa dalam pembangunan dan pengelolaan dana Desa (studi kasus di Desa Ncandi Kecamatan Madapangga Kabupaten
Bima) sudah berjalan dengan maksimal, hal tersebut terlihat dari Hubungan kerjasama BPD dengan Kepala Desa, Kerjasama Dalam membuat Rencana Kerja Pemerintah Desa (RKP Desa) dan APBdesa, Kemudian terlihat juga dari Tahapan-tahapan kerjasama BPD dengan pemerintah Desa dalam pembangunan dan pengelolaan dana Desa.

Kedua, Walaupun kerjasama BPD dengan Pemerintah Desa sudah maksimal namum tetap saja memiliki kendala-kendala yang di hadapi dalam kerjasama tersebut yaitu: 1) Kendala Dalam membuat perencanaan pembangunan Desa melalui Musremabang Desa. 2) Masalah sulitnya mengambil keputusan karena banyaknya kebutuhan masyarakat dan kelompokkelompok masyarakat. 3) Kendala Dalam penyelenggaraan kegiatan pembangunan Desa 4) Kendala dari persetujuan Pemerintah Daerah.

Penelitian merekomendasikan untuk:

(1) Pemerintah Desa Ncandi agar mensosialisasikan keberadaan Undang-Undang Nomor 6 Tahun 2014 tentang Desa kepada masyarakat agar masyarakat memahami serta bisa melakukan pengawasan terhadap kinerja Pemerintah Desa.

(2) KepadaBPD di harapkan agar lebih akuntabilitas lagi dalam mengemban amanah sebagai lembaga legislativenya di tinggkat Desa serta melakukan pelatihan-pelatihan khusus kaitanya dengan tugas dan fungsinya sebangai DPR di tingkat Desa.

(3) Kepada masyarakat Desa Ncandi diharapkan agar lebih melibatkan diri ketika ada kegiatan Desa maupun dalam pembangunan dengan mengutamakan konsep gotong royong.

\section{UCAPAN TERIMA KASIH}

Penulis mengucapkan terima kasih kepada editor yang senantiasa memberikan saran dan masukan kepada penulis sehingga artikel ilimiah ini selesai dengan baik.

\section{DAFTAR RUJUKAN}

[1] H. M. Busrizalti, "Hukum Pemda Otonomi dan Aplikasinya.” Total Media, Yogyakarta, 2013.

[2] B. Sugiswati, "Perlindungan hukum terhadap eksistensi masyarakat adat di indonesia," vol. XVII, no. 1, pp. 31-43, 2012.

[3] S. Djam'an, "Profesi Keguruan," Jakarta Univ. Terbuka, 2007.

[4] L. J. Moleong, Metodologi penelitian. 1999.

[5] A. Suharsimi, "Prosedur penelitian suatu pendekatan praktik,” Jakarta: Rineka Cipta, 2006.

[6] M. B. Milles, "Huberman. 1984. Qualitative Data Analysis." London: Sage Publication.

[7] P. Sugiyono, Metode Penelitian Kuantitatif, Kualitatif, dan $R \& D .2013$.

[8] U.-U. R. I. Nomor, "Undang-Undang No. 6 tahun 2014 tentang Desa,” Pemerintah Negara Republik Indones. Jakarta, 6AD. 